\title{
Effective Preemergence and Postemergence Herbicide Programs for Kochia Control
}

\section{Authors: Vipan Kumar \& Prashant Jha}

This is a postprint of an article that originally appeared in Weed Technology on March 2015.

Kumar, Vipan, and Prashant Jha. "Effective Preemergence and Postemergence Herbicide Programs for Kochia Control.” Weed Technology 29, no. 1 (March 2015): 24-34. doi: $10.1614 / \mathrm{wt}-\mathrm{d}-14-00026.1$.

Made available through Montana State University's ScholarWorks 


\title{
Effective Preemergence and Postemergence Herbicide Programs for Kochia Control
}

\author{
Vipan Kumar and Prashant Jha*
}

Field experiments were conducted in 2011 through 2013 at the MSU Southern Agricultural Research Center near Huntley, MT, to evaluate the effectiveness of various PRE and POST herbicide programs for kochia control in the absence of a crop. PRE herbicides labeled for corn, grain sorghum, soybean, wheat/barley, and/or in chemical fallow were applied at recommended field-use rates. Acetochlor + atrazine, $S$-metolachlor + atrazine + mesotrione, and sulfentrazone applied PRE provided $\geq 91 \%$ control of kochia at $12 \mathrm{wk}$ after treatment (WAT). Metribuzin, metribuzin + linuron, and pyroxasulfone + atrazine PRE provided $82 \%$ control at 12 WAT. PRE control with acetochlor + flumetsulam + clopyralid, pyroxasulfone alone, and saflufenacil $+2,4-\mathrm{D}$ was $\leq 23 \%$ at 12 WAT. Paraquat + atrazine, paraquat + linuron, and paraquat + metribuzin controlled kochia $\geq 98 \%$ at 5 WAT. POST control with bromoxynil + fluroxypyr, paraquat, tembotrione + atrazine, and topramezone + atrazine treatments averaged $84 \%$ at 5 WAT, and did not differ from glyphosate. Control with POST-applied bromoxynil + pyrasulfotole, dicamba, diflufenzopyr + dicamba +2,4-D, saflufenacil, saflufenacil $+2,4-\mathrm{D}$, saflufenacil + linuron was 67 to $78 \%$ at 5 WAT. Because of the presence of kochia resistant to acetolactate synthase-inhibiting herbicides at the test site, cloransulammethyl was not a viable option for kochia control. In a separate greenhouse study, kochia accessions showed differential response to the POST herbicides (labeled for corn or soybean) tested. Tembotrione + atrazine, topramezone + atrazine, lactofen, or fomesafen effectively controlled the glyphosate-resistant kochia accession tested. Growers should utilize these effective PRE- or POSTapplied herbicide premixes or tank mixtures (multiple modes of action) to control herbicide-resistant kochia accessions in the field. PRE herbicides with 8 wk of soil-residual activity on kochia would be acceptable if crop competition were present; however, a follow-up herbicide application may be needed to obtain season-long kochia control in the absence of crop competition.

Nomenclature: 2,4-D; acetochlor; atrazine; bromoxynil; carfentrazone-ethyl; clopyralid; cloransulam-methyl; dicamba; diflufenzopyr; flumetsulam; flumioxazin; fluroxypyr; fomesafen; glufosinate; glyphosate; isoxaflutole; lactofen; linuron; MCPA; mesotrione; metolachlor; paraquat; pyrasulfotole; pyroxasulfone; saflufenacil; sulfentrazone; tembotrione; thifensulfuron; tribenuron; topramezone; kochia, Kochia scoparia (L.) Schrad.

Key words: Glyphosate-resistant kochia, herbicide efficacy, residual control, herbicide resistance management, weed control. 
Kochia is one of the most troublesome summer annual broadleaf weeds in croplands and noncroplands across the Great Plains of North America (Eberlein and Fore 1984; Forcella 1985; Wicks et al. 1994). The invasiveness of kochia is attributed to its unique biological characteristics, including early seedling emergence, $\mathrm{C}_{4}$ photosynthesis, rapid growth rates, heat and salt tolerance, prolific seed production $\left(>50,000\right.$ seeds plant $\left.{ }^{-1}\right)$, and longdistance seed dispersal by tumbling (Baker et al. 2010; Christoffoleti et al. 1997; Friesen et al. 2009; Schwinghamer and Van Acker 2008). Furthermore, the protogynous nature of kochia flowering enforces a high degree of outcrossing and pollen-mediated gene flow (Mengistu and Messersmith 2002; Stallings et al. 1995). Consequently, the presence of high genetic diversity within and among kochia accessions has also been reported (Mengistu and Messersmith 2002).

Kochia causes season-long interference and yield reductions in agronomic crops of the Great Plains, including wheat (Triticum aestivum L.), corn (Zea mays L.), sorghum (Sorghum bicolor L.), sugar beet (Beta vulgaris L.), sunflower (Helianthus annus L.), and soybean [Glycine $\max$ (L.) Merr]. Season-long interference of kochia can reduce soybean, sorghum, wheat, corn, and sugar beet yields by $30,38,58,40$, and 95\%, respectively (Dahl et al. 1982; Durgan et al. 1990; Waite et al. 2013; Weatherspoon 1971; Wicks et al. 1993, 1994).

Growers in the northern and central Great Plains are facing ever-increasing challenges in controlling kochia because of the widespread occurrence of kochia accessions resistant to one or more herbicide chemistries (Heap 2014). Kochia resistance to herbicide modes of action including group 5 (atrazine), group 2 (sulfonylurea and imidazolinone herbicides), group 4 (dicamba and fluroxypyr), and more recently to group 9 (glyphosate) has been reported in this region (Cranston et al. 2001; Heap 2014; Kumar et al. 2014; Preston et al. 2009; Primiani et al. 1990). Glyphosate-resistant (Gly-R) kochia has been reported in seven U.S. states and in Alberta, Canada (Beckie et al. 2013; Heap 2014).
The escalating spread of Gly-R kochia is a potential threat to Gly-R cropping systems and to the no-till chemical fallow wheat rotation common in the region. Occurrence of Gly-R kochia accessions with 4.6- to 11-fold levels of resistance to glyphosate has been recently confirmed in chemical-fallow (chemical-fallow and wheat rotation) fields of Hill, Liberty, and Toole Counties of Montana (Kumar et al. 2014).

Weed control programs aimed at managing herbicide-resistant weeds recommend the use of annual herbicide rotation and tank mixtures with multiple modes of action (Beckie et al. 2006; Norsworthy et al. 2012). Diversifying herbicide programs with the use of soil-applied residual PRE herbicides in conjunction with effective POST herbicides is critical for management of herbicideresistant weeds (Norsworthy et al. 2012; Stephenson et al. 2013). Previous researchers have reported variable levels of kochia control with PRE or POST herbicides. In addition, use of a single-mode-ofaction herbicide often results in inconsistent control of kochia. For instance, kochia control with flumioxazin $\left(0.28 \mathrm{~kg}\right.$ ai ha $\left.{ }^{-1}\right)$, pendimethalin $(1.4$ $\mathrm{kg}$ ai $\left.\mathrm{ha}^{-1}\right)$, or pyroxasulfone $\left(0.42 \mathrm{~kg}\right.$ ai ha $\left.{ }^{-1}\right)$ applied alone PRE was only 53 to $70 \%$ (Lloyd et al. 2011; Stahlman et al. 2010). Among POST herbicides tested by Lloyd et al. (2011), control with either fluroxypyr or glyphosate did not exceed $75 \%$, and was as low as 35\% with saflufenacil alone. Although bromoxynil + MCPA, carfentrazone, or paraquat applied POST controlled kochia $\geq 90 \%$ under greenhouse conditions (Nandula and Manthey 2002; Tonks and Westra 1997), control as low as $68 \%$ was observed with those herbicides under field conditions (Wicks et al. 1993). This might be due to potential regrowth of the treated plants or lack of residual activity of the herbicide on cohort(s) that emerged after the POST application, which obviates the need to investigate effective PRE- or POST-applied herbicide combinations (multiple modes of action) for full-season kochia control.

The ever-increasing frequency of herbicide-resistant kochia is a major threat to the Great Plains 
Table 1. Mean monthly air temperature and total precipitation at the Montana State University Southern Agricultural Research Center near Huntley, MT.

\begin{tabular}{|c|c|c|c|c|c|c|}
\hline \multirow[b]{2}{*}{ Month } & \multicolumn{3}{|c|}{ Temperature } & \multicolumn{3}{|c|}{ Total precipitation } \\
\hline & 2011 & 2012 & 2013 & 2011 & 2012 & 2013 \\
\hline & & $-\mathrm{C}-$ & & & $-\mathrm{mm}-$ & . \\
\hline March & 3 & 8 & 3 & 20.1 & 45.0 & 5.8 \\
\hline April & 6 & 10 & 6 & 68.6 & 22.6 & 29.7 \\
\hline May & 11 & 13 & 14 & 237.5 & 82.3 & 154.2 \\
\hline June & 17 & 20 & 19 & 39.1 & 9.9 & 35.8 \\
\hline July & 23 & 25 & 23 & 67.3 & 12.2 & 16.5 \\
\hline August & 23 & 22 & 23 & 16.0 & 9.1 & 36.6 \\
\hline
\end{tabular}

cropping systems. Although alternative (nonglyphosate) herbicide options for Gly-R kochia control in wheat-fallow rotation has been recently documented (Kumar et al. 2014), there is no published research on alternative herbicides for effective control of Gly-R kochia in Gly-R corn or soybean in the Great Plains. The objectives of this research were to determine effective PRE and POST herbicide programs for kochia control in the field, and to test the effectiveness of alternative (nonglyphosate) POST herbicides labeled in corn or soybean for control of Gly-R kochia accessions.

\section{Materials and Methods}

PRE Herbicide Programs. Field experiments were initiated at the Montana State University (MSU) Southern Agricultural Research Center (SARC) near Huntley, MT, in 2011, and repeated in 2012 and 2013, to test the effectiveness of soil-applied PRE herbicides labeled for corn, grain sorghum, soybean, wheat/barley, and/or chemical-fallow for kochia control. Experiments were conducted in a fallow situation for long-term evaluation of herbicide efficacy. The soil type at the study location was a Fort Collins clay loam (fine-loamy, mixed, superactive, mesic Aridic Haplustalfs) with 2.8\% organic matter and a $\mathrm{pH}$ of 7.8. Monthly mean air temperatures and total precipitation during the study periods are shown in Table 1 . The experimental site was in a minimum of 5-yr no-till dryland wheat-fallow rotation prior to the initiation of the study. Each year, the experimental site was moved to avoid any residual activity from herbicides applied the previous year. Historically, each experimental site had received two or three applications of glyphosate during the summer fallow period, and fluroxypyr and bromoxynil plus MCPA in the wheat crop for weed control. Furthermore, the sites selected had no history of kochia infestation. During fall of each year, fully matured kochia seeds were collected from a naturally infested area at the MSU-SARC research farm. Seeds were broadcasted in the fall to obtain uniform kochia densities in plots the following spring. PRE herbicide programs included in the study and their application date each year are presented in Tables 2 and 3. A nontreated control was included for comparison. PRE herbicide treatments were applied at their recommended field-use rates with a $\mathrm{CO}_{2}$-pressurized backpack sprayer equipped with flat-fan nozzles (TeeJet 8001XR, Spraying Systems Co., P.O. Box 7900, Wheaton, IL), calibrated to deliver $94 \mathrm{~L} \mathrm{ha}^{-1}$ of spray solution at $276 \mathrm{kPa}$.

Experiments were conducted in a randomized complete block design with four replications, and plot size of $2 \times 4.5 \mathrm{~m}$. Kochia densities were recorded within $1-\mathrm{m}^{2}$ quadrats placed at the center of a nontreated plot (Table 3). Percent control of kochia from PRE herbicides was visually rated at 6 , 8,10 , and 12 wk after treatment (WAT) on a scale of 0 to $100 \%$ (0 being no control and 100 being complete control). Visual assessments for percent control were based on emergence and general suppression/stunting of kochia seedlings in treated compared with nontreated plots.

POST Herbicide Programs. Separate field experiments were conducted at the MSU-SARC near Huntley, in 2011, 2012, and 2013, to evaluate the effectiveness of various POST herbicide programs for kochia control. The soil and environmental conditions were similar to those described in the PRE herbicide trials. POST herbicide experiments were also conducted in a crop-free situation. In the fall of each year, the experimental site was uniformly infested with kochia seeds as described previously, and was kept free from other weed species throughout the growing season by hand weeding. POST herbicides labeled in wheat/barley, corn/ grain sorghum, soybean, or chemical-fallow was selected. A nontreated control was included for comparison. POST herbicides were applied at their recommended field-use rates when kochia plants were 8 to $10 \mathrm{~cm}$ tall (Tables 3 and 4) in the field, with the use of a $\mathrm{CO}_{2}$-pressurized backpack sprayer described above. 
Table 2. List of PRE herbicides treatments for kochia control in 2011, 2012, and 2013 at the Montana State University Southern Agricultural Research Center near Huntley, MT.

\begin{tabular}{|c|c|c|c|}
\hline Herbicide(s) & Trade name & Application rate & Manufacturer \\
\hline & \multicolumn{3}{|c|}{$\left(\mathrm{kg}\right.$ ai or ae $\left.\mathrm{ha}^{-1}\right)$} \\
\hline Acetochlor + atrazine & HarnessXtra5.6L & $2.604+2.100$ & $\begin{array}{c}\text { Monsanto Company, } 800 \text { North } \\
\text { Lindberg Ave., St. Louis, MO }\end{array}$ \\
\hline $\begin{array}{l}\text { Acetochlor }+ \text { flumetsulam } \\
\quad+\text { clopyralid }\end{array}$ & TripleFlex & $1.047+0.033+0.106$ & Monsanto \\
\hline Dicamba & Rifle & 0.280 & Loveland Products Inc., Greeley, CO \\
\hline Dicamba $+2,4-\mathrm{D}$ amine & Rifle + Weedar 64 & $0.280+0.560$ & $\begin{array}{l}\text { Loveland Products and Nufarm, Inc., } \\
\text { Burr Ridge, IL }\end{array}$ \\
\hline Dicamba + pendimethalin & Rifle + Prowl ${ }^{\circledR} \mathrm{H} 2 \mathrm{O}$ & $0.280+0.798$ & $\begin{array}{l}\text { Loveland Products and BASF } \\
\text { Corporation, 26 Davis Drive, } \\
\text { Research Triangle Park, NC } 27709\end{array}$ \\
\hline Flumioxazin & Valor & 0.070 & $\begin{array}{l}\text { Valent U.S.A. Corporation, Walnut } \\
\text { Creek, CA }\end{array}$ \\
\hline Flumioxazin + pyroxasulfone & Fierce & 0.188 & Valent U.S.A. \\
\hline Isoxaflutole & Balance $^{\circledR}$ flexx & 0.062 & $\begin{array}{l}\text { Bayer Crop Science, Research Triangle } \\
\text { Park, NC } 27709\end{array}$ \\
\hline Metribuzin & Sencor ${ }^{\circledR} 75 \mathrm{DF}$ & 0.425 & Bayer Crop Science \\
\hline Metribuzin + linuron & Sencor $^{\circledR} 75 \mathrm{DF}+$ Linex $^{\circledR} 4 \mathrm{~L}$ & $0.425+0.840$ & $\begin{array}{l}\text { Bayer Crop Science and Tessenderlo } \\
\text { Kerley Inc., Phoenix, AZ }\end{array}$ \\
\hline Pyroxasulfone & Zidua & 0.118 & BASF \\
\hline Pyroxasulfone + atrazine & Zidua + AAtrex $^{\circledR} 4 \mathrm{~L}$ & $0.118+0.560$ & $\begin{array}{l}\text { BASF and Syngenta Crop Protection, } \\
\text { Inc., Greensboro, NC }\end{array}$ \\
\hline $\begin{array}{l}\text { Saflufenacil }+2,4-\mathrm{D} \\
S \text {-metolachlor }+ \text { atrazine }\end{array}$ & Sharpen + Weedar 64 & $0.025+0.560$ & BASF and Nufarm \\
\hline+ mesotrione & Lumax & $0.855+0.319+0.085$ & Syngenta Crop Protection \\
\hline Sulfentrazone & Spartan & 0.210 & FMC Corporation, Philadelphia, PA \\
\hline
\end{tabular}

The experimental design was a randomized complete block with four replications. Kochia densities were recorded within $1-\mathrm{m}^{2}$ quadrats placed at the center of each plot $(2 \times 4.5 \mathrm{~m}) 1 \mathrm{~d}$ prior to the POST herbicide application (Table 3). Kochia control was recorded at 1,3 , and 5 WAT on a scale of 0 to $100 \%$ ( 0 being no control and 100 being

Table 3. Average kochia density and application dates of PRE and POST herbicides in 2011, 2012, and 2013 at the Montana State University Southern Agricultural Research Center near Huntley, MT.

\begin{tabular}{cccccc}
\hline & \multicolumn{2}{c}{ Kochia density } & & \multicolumn{2}{c}{ Herbicide application date } \\
\cline { 2 - 3 } \cline { 5 - 6 } Years & PRE $^{\mathrm{a}}$ & POST $^{\mathrm{b}}$ & & PRE & POST \\
\hline & - plants $\mathrm{m}^{-2}-$ & & \\
2011 & 54 & 79 & & April 26 & June 12 \\
2012 & 78 & 94 & & April 24 & June 10 \\
2013 & 69 & 108 & & April 28 & June 14 \\
\hline
\end{tabular}

\footnotetext{
${ }^{a}$ In the PRE herbicide study, kochia densities were recorded 3 wk after emergence in the nontreated plots.

b In the POST herbicide study, kochia densities were recorded $1 \mathrm{~d}$ prior to the application of the POST herbicides.
}

complete control). Visual assessments for percent control were based on general chlorosis, stunting, or necrosis of treated plants.

Gly-R Kochia Control. Experiments were conducted in a greenhouse at the MSU-SARC near Huntley during spring 2013, to determine the response of Gly-R kochia accessions to alternative POST herbicides (labeled in corn or soybean). The effectiveness of various POST herbicides was tested on four confirmed Gly-R kochia accessions from MT including GIL01, JOP01, CHES01, and CHES02 (as described in Kumar et al. 2014) in comparison to a known glyphosate-susceptible (Gly-S) accession. The Gly-R GIL01 and JOP01 accessions were collected in fall 2012 from two different fields within $5 \mathrm{~km}$ of each other in Hill County, MT; Gly-R CHES01 and CHES02 were collected from two separate fields within $3 \mathrm{~km}$ of each other near Chester, Liberty County, MT. The glyphosate-susceptible (Gly-S) accession was collected in fall 2012 from a field near Huntley used for long-term organic trials. Seeds of Gly-R and 
Table 4. List of burndown and in-crop POST herbicide treatments for kochia control in 2011, 2012, and 2013 at the Montana State University Southern Agricultural Research Center near Huntley, MT.

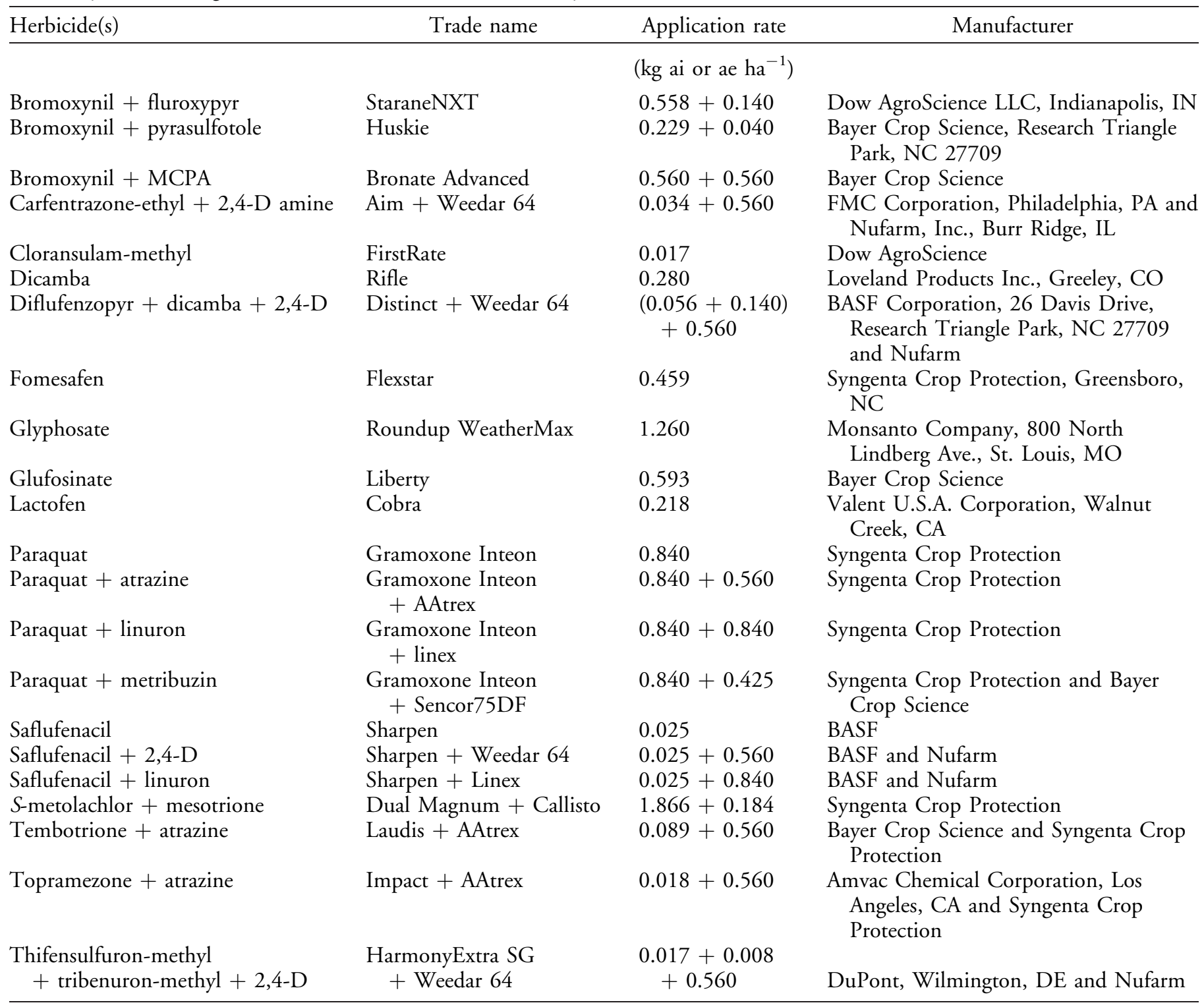

Gly-S accessions were sown separately on the surface of 53 by 35 by $10 \mathrm{~cm}$ flats filled with a commercial potting media (VermiSoil ${ }^{\mathrm{TM}}$, Vermicrop Organics, 4265 Duluth Avenue, Rocklin, CA). Single kochia seedlings were transplanted into 10 -cm-diam pots containing the same potting medium as the germination flats. Experiments were arranged in a randomized complete block design with eight replications (one plant per pot) for each accession and herbicide combination, and the experiment was repeated. The greenhouse was maintained at 26/23 $\pm 3 \mathrm{C}$ day/night temperatures with $16 / 8 \mathrm{~h}$ day/ night photoperiods, and the supplemental photo- period was obtained with metal halide lamps (400 $\mu \mathrm{mol} \mathrm{m} \mathrm{s}^{-1}$ ).

Alternative herbicide programs included in the study and their application rates are summarized in Table 5. All herbicides were applied at their recommended field-use rates to 8 - to $10-\mathrm{cm}$-tall kochia plants with the use of a cabinet spray chamber (Research Track Sprayer, De Vries Manufacturing, RR 1 Box 184, Hollandale, MN) equipped with a flat-fan nozzle tip (TeeJet 8001 XR) calibrated to deliver $94 \mathrm{~L} \mathrm{ha}^{-1}$ of spray solution at $276 \mathrm{kPa}$. After the herbicide application, plants were returned to the greenhouse, watered daily to 
Table 5. List of alternative POST herbicides for glyphosate-resistant (Gly-R) kochia control.

\begin{tabular}{|c|c|c|c|}
\hline Herbicide $(s)^{\mathrm{a}, \mathrm{b}}$ & Trade name & Application rate & Manufacturer \\
\hline \multicolumn{4}{|c|}{$\left(\mathrm{kg}\right.$ ai or ae $\left.\mathrm{ha}^{-1}\right)$} \\
\hline Cloransulam-methyl ${ }^{\mathrm{c}}$ & FirstRate & 0.017 & Dow AgroScience LLC, Indianapolis, IN \\
\hline Fomesafen $^{c}$ & Flexstar & 0.459 & $\begin{array}{l}\text { Syngenta Crop Protection, Inc. Greensboro, } \\
\text { NC }\end{array}$ \\
\hline Lactofen $^{\mathrm{d}}$ & Cobra & 0.218 & Valent U.S.A. Corporation, Walnut Creek, CA \\
\hline$S$-metolachlor + mesotrione ${ }^{c}$ & Dual Magnum + Callisto & $1.866+0.184$ & Syngenta Crop Protection \\
\hline Tembotrione $^{\mathrm{d}}$ & Laudis & 0.089 & Bayer CropScience, Research Triangle Park, NC \\
\hline Tembotrione + atrazine $^{\mathrm{d}}$ & Laudis + AAtrex & $0.089+0.560$ & $\begin{array}{l}\text { Bayer CropScience and Syngenta Crop } \\
\text { Protection }\end{array}$ \\
\hline Topramezone ${ }^{\mathrm{d}}$ & Impact & 0.018 & Amvac Chemical Corporation, Los Angeles, CA \\
\hline Topramezone + atrazine $^{\mathrm{d}}$ & Impact + AAtrex & $0.018+0.560$ & $\begin{array}{l}\text { Amvac Chemical Corporation and Syngenta } \\
\text { Crop Protection }\end{array}$ \\
\hline
\end{tabular}

${ }^{\text {a }}$ Herbicides are labeled for corn or soybean

b All treatments were applied to 8- to 10-cm-tall kochia plants.

${ }^{\mathrm{c}}$ Nonionic surfactant (NIS) at $0.25 \%(\mathrm{v} / \mathrm{v})$ was included.

${ }^{\mathrm{d}}$ Methylated seed oil (MSO) at $1 \%(\mathrm{v} / \mathrm{v})$ was included.

avoid moisture stress, and fertilized (Miracle-Gro water soluble fertilizer [24-8-16], Scotts MiracleGro Products Inc., 14111 Scottslawn Road, Marysville, $\mathrm{OH}$ ] weekly to maintain good growth.

Percent control of kochia was visually assessed at 1,2 , and 3 WAT with the use of the rating scale described for the field experiments. At 3 WAT, kochia plants were harvested at the soil level, and shoot dry weights were determined after ovendrying the samples at $60 \mathrm{C}$ for $3 \mathrm{~d}$. For each kochia accession, shoot dry weight data were expressed as percentage of the nontreated control.

Statistical Analyses. All data from field and greenhouse experiments were subjected to ANOVA with the use of the PROC MIXED procedure in SAS (Statistical Analysis Systems ${ }^{\circledR}$, version 9.2, SAS Institute Inc., SAS Campus Drive, Cary, NC 27513).Variances were divided into random effects (year or run, replication nested within a year or run, and interactions involving either of these two variables) and fixed effects (herbicide treatment for the field studies or herbicide treatment, accession, and their interaction for the greenhouse study). Data on percent control and shoot dry weight (percent of nontreated) were arcsine-square-root transformed before analysis to improve the normality of residuals and homogeneity of variance. Nontransformed means are presented in tables based on the interpretation from the transformed data. Control data from nontreated plots were not included in the analyses. Means were separated with the use of Fisher's protected LSD test at $\mathrm{P}<0.05$.

\section{Results and Discussion}

The majority of the kochia emerged between May 10 and May 18 each year. Mean air temperatures during the month of May were 11, 13, and $14 \mathrm{C}$, in 2011, 2012, and 2013, respectively (Table 1). There was sufficient soil moisture from the major precipitation events (totaling $\geq 76 \mathrm{~mm}$ ) that occurred between April 25 and May 10 each year to activate the PRE herbicides.

PRE Herbicide Programs. Kochia densities in PRE herbicide experiments ranged from 54 to 78 plants $\mathrm{m}^{-2}$ over the $3 \mathrm{yr}$ (Table 3 ). Kochia control with acetochlor + atrazine, dicamba + pendimethalin, isoxaflutole, metribuzin, metribuzin + linuron, pyroxasulfone + atrazine, $S$-metolachlor + atrazine + mesotrione, and sulfentrazone treatments applied PRE was 93 to $100 \%$ at 8 WAT (Table 6). Flumioxazin + pyroxasulfone and dicamba alone or with 2,4-D PRE provided 84 to $90 \%$ control 8 WAT (Table 6). PRE control with flumioxazin + pyroxasulfone $(90 \%)$ was superior to flumioxazin alone $(66 \%)$ or pyroxasulfone alone $(61 \%) 8$ WAT.

Consistent with the previous evaluation dates (8 and 10 WAT), control at 12 WAT with acetochlor + atrazine, acetochlor + atrazine + mesotrione, and sulfentrazone was $>90 \%$ (Table 6). In previous research, poor kochia control $(<50 \%)$ has been 
Table 6. Kochia control at 8, 10, and $12 \mathrm{wk}$ after treatment (WAT) with various PRE herbicide treatments at the Montana State University Southern Agricultural Research Center near Huntley, MT.,

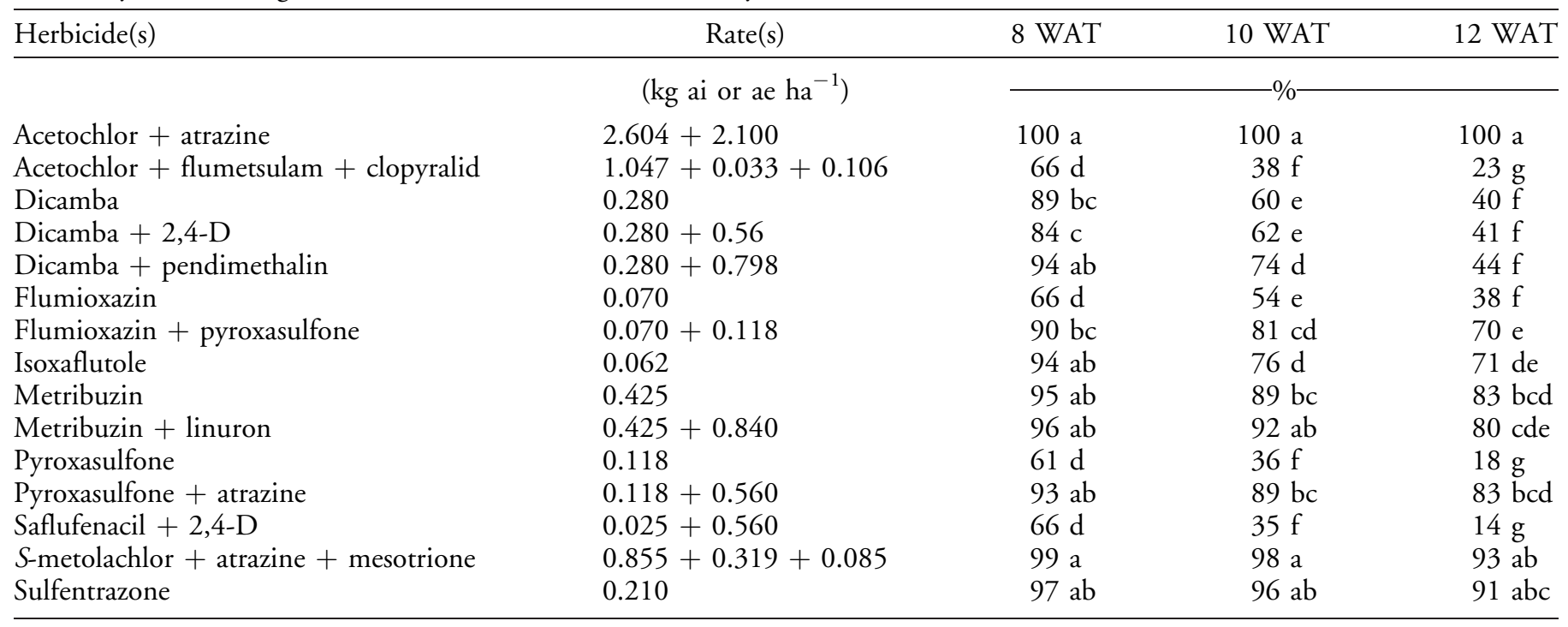

${ }^{a}$ PRE treatments were applied prior to kochia emergence in the field.

b Means within a column followed by similar letters are not significantly different based on Fisher's protected LSD test at P $<0.05$.

reported with acetochlor $\left(1.960 \mathrm{~kg}\right.$ ai $\left.\mathrm{ha}^{-1}\right)$ or metolachlor $\left(1.070 \mathrm{~kg}\right.$ ai ha $\left.{ }^{-1}\right)$ applied PRE in sunflower and corn (Jha et al. 2013; Reddy et al. 2012). Although atrazine-alone treatment was not included in this study, consistent control of kochia (up to 12 WAT) obtained with acetochlor + atrazine was possibly due to the residual activity of atrazine on kochia. However, widespread occurrence of triazine-resistant kochia in the U.S. Great Plains (Heap 2014) limits the use of atrazine as a stand-alone PRE herbicide in corn. Control with metribuzin, metribuzin + linuron, and pyroxasulfone + atrazine was 80 to $83 \% 12$ WAT.

Control with flumioxazin + pyroxasulfone and isoxaflutole declined from 92 to $70 \%$ at 12 WAT. Also, residual activity of dicamba, dicamba $+2,4-\mathrm{D}$, dicamba + pendimethalin, and flumioxazin declined up to $50 \%$ by 12 WAT (Table 6). A shift in kochia accession to late-emerging cohorts was a mechanism to escape residual activity of isoxaflutole applied PRE in corn over 8 yr (Sbatella and Wilson 2010). Our results further suggest that kochia has an extended period of emergence (Dille et al. 2012). Although sequential herbicide applications may be desirable to obtain season-long kochia control in fallow with some of the PRE herbicides tested, treatments providing high residual control for $8 \mathrm{wk}$ (Table 6) may still be acceptable in the presence of a crop that will compete with the late-emerging kochia cohort(s). Performance of acetochlor + flumetsulam + clopyralid, pyroxasulfone alone, or saflufenacil $+2,4-\mathrm{D}$ was poor, with PRE control as low as $14 \%$ at 12 WAT.

POST Herbicide Programs. Kochia densities at the experimental sites ranged from 79 to 108 plants $\mathrm{m}^{-2}$ (Table 3). Paraquat + atrazine provided $100 \%$ control at all evaluation dates, and was comparable to paraquat + linuron and paraquat + metribuzin treatments (Table 7). The results indicate a combined soil and foliar activity of these effective herbicide mixtures on kochia.

POST control 1 WAT with bromoxynil + fluroxypyr, bromoxynil + pyrasulfotole, glyphosate, saflufenacil + linuron, and tembotrione + atrazine treatments was 92 to $95 \%$ (Table 7). Control with bromoxynil + MCPA, carfentrazone-ethyl + 2,4-D, glufosinate, lactofen, and saflufenacil was 87 to $90 \%$ 1 WAT. Control with dicamba alone, diflufenzopyr + dicamba $+2,4-\mathrm{D}$, and topramezone + atrazine was $82 \%$ at 1 WAT. Fomesafen and $S$-metolachlor + mesotrione applied POST provided 62 to $77 \%$ control of kochia 1 WAT. Control with cloransulam-methyl and thifensulfuron + tribenuron (Group 2, acetolactate synthase [ALS] inhibitor herbicides) $+2,4 \mathrm{D}$ was 35 and $57 \%$, respectively, which was due to the presence of ALS-inhibitorresistant kochia at the experimental sites (data not shown). 
Table 7. Kochia control at 1, 3, and $5 \mathrm{wk}$ after treatment (WAT) with various POST herbicide treatments at the Montana State University Southern Agricultural Research Center near Huntley, MT.

\begin{tabular}{|c|c|c|c|c|}
\hline Herbicide(s) ${ }^{\mathrm{a}}$ & Rate(s) & $1 \mathrm{WAT}^{\mathrm{b}}$ & 3 WAT & 5 WAT \\
\hline & $\left(\mathrm{kg}\right.$ ai or ae $\left.\mathrm{ha}^{-1}\right)$ & & $\%$ & \\
\hline Bromoxynil + fluroxypyr ${ }^{c}$ & $0.558+0.140$ & $95 \mathrm{bcd}$ & 92 cde & 82 bcd \\
\hline Bromoxynil + pyrasulfotole $^{\mathrm{c}, \mathrm{d}}$ & $0.229+0.040$ & $92 \mathrm{de}$ & $85 \mathrm{fg}$ & $77 \mathrm{de}$ \\
\hline Bromoxynil + MCPA & $0.560+0.560$ & $87 \mathrm{fg}$ & $77 \mathrm{jk}$ & $65 \mathrm{fg}$ \\
\hline Carfentrazone-ethyl $+2,4-\mathrm{D}^{\mathrm{c}}$ & $0.034+0.560$ & $87 \mathrm{fg}$ & 82 ghi & $60 \mathrm{gh}$ \\
\hline Cloransulam-methyl $^{\mathrm{c}}$ & 0.017 & $351^{\circ}$ & $32 \mathrm{o}$ & $18 \mathrm{~m}$ \\
\hline Dicamba & 0.280 & $82 \mathrm{~h}$ & $78 \mathrm{ij}$ & $77 \mathrm{de}$ \\
\hline Diflufenzopyr + dicamba $+2,4-D^{c}$ & $0.056+0.140+0.560$ & $83 \mathrm{gh}$ & 82 ghi & $78 \mathrm{cde}$ \\
\hline Fomesafen ${ }^{c}$ & 0.459 & $77 \mathrm{i}$ & 721 & 401 \\
\hline Glyphosate $^{\mathrm{d}}$ & 1.260 & $95 \mathrm{bcd}$ & $93 \mathrm{~cd}$ & $88 \mathrm{~b}$ \\
\hline Glufosinate $^{\mathrm{d}}$ & 0.593 & $87 \mathrm{fg}$ & $73 \mathrm{kl}$ & $52 \mathrm{ij}$ \\
\hline Lactofen $^{\mathrm{e}}$ & 0.218 & 88 ef & 80 hij & $57 \mathrm{hi}$ \\
\hline Paraquat $^{\mathrm{c}}$ & 0.840 & $99 \mathrm{ab}$ & $95 \mathrm{bc}$ & $85 \mathrm{bc}$ \\
\hline Paraquat + atrazine $^{c}$ & $0.840+0.560$ & $100 \mathrm{a}$ & $100 \mathrm{a}$ & $100 \mathrm{a}$ \\
\hline Paraquat + linuron $^{\mathrm{c}}$ & $0.840+0.840$ & $99 \mathrm{ab}$ & $99 \mathrm{ab}$ & $98 \mathrm{a}$ \\
\hline Paraquat + metribuzin $^{c}$ & $0.840+0.425$ & $99 \mathrm{ab}$ & $98 \mathrm{ab}$ & $98 \mathrm{a}$ \\
\hline Saflufenacil d,e & 0.025 & 90 ef & 82 ghi & 67 ef \\
\hline Saflufenacil $+2,4-D^{\mathrm{d}, \mathrm{e}}$ & $0.025+0.560$ & $97 \mathrm{abc}$ & $83 \mathrm{gh}$ & 72 ef \\
\hline Saflufenacil + linuron $^{\mathrm{d}, \mathrm{e}}$ & $0.025+0.840$ & $95 \mathrm{bcd}$ & $90 \mathrm{de}$ & 78 cde \\
\hline$S$-metolachlor + mesotrione ${ }^{c}$ & $1.866+0.184$ & $62 \mathrm{j}$ & $57 \mathrm{~m}$ & 48 jk \\
\hline Tembotrione + atrazine $e^{e}$ & $0.089+0.560$ & $93 \mathrm{cde}$ & 88 ef & $85 \mathrm{bc}$ \\
\hline Topramezone + atrazine $e^{e}$ & $0.018+0.560$ & $83 \mathrm{gh}$ & $83 \mathrm{gh}$ & $80 \mathrm{~cd}$ \\
\hline Thifensulfuron + tribenuron $+2,4-\mathrm{D}^{\mathrm{c}}$ & $0.017+0.008+0.560$ & $57 \mathrm{k}$ & $48 \mathrm{n}$ & $43 \mathrm{kl}$ \\
\hline
\end{tabular}

${ }^{a}$ Herbicide treatments were applied to 8- to 10 -cm-tall kochia plants in the field.

${ }^{\mathrm{b}}$ Means within a column followed by similar letters are not significantly different based on Fisher's protected LSD test at $\mathrm{P}<0.05$.

${ }^{\mathrm{c}}$ Nonionic surfactant (NIS) at $0.25 \% \mathrm{v} / \mathrm{v}$ was included.

${ }^{\mathrm{d}}$ Ammonium sulfate (AMS) at $2 \% \mathrm{w} / \mathrm{v}$ was included.

${ }^{\mathrm{e}}$ Methylated seed oil (MSO) at $1 \% \mathrm{v} / \mathrm{v}$ was included.

In general, kochia control declined by 3 or 5 WAT compared to 1 WAT with majority of the POST herbicides tested (Table 7), except paraquat + atrazine, paraquat + linuron, or paraquat + metribuzin treatments. The observed decline in control was partially due to recovery of treated plants from the herbicide injury and/or survival of late-emerging (July) kochia plants that escaped the POST herbicide application in the absence of a residual tank-mix partner.

In a greenhouse study, Wicks et al. (1993) also reported $>95 \%$ control of 7.5 - to $10-\mathrm{cm}$-tall kochia plants treated with paraquat $\left(0.3 \mathrm{~kg} \mathrm{ha}^{-1}\right) 15$ DAT. Although carfentrazone or fluroxypyr were not tested alone in our study, $>88 \%$ kochia control was reported with carfentrazone $\left(0.02 \mathrm{~kg}\right.$ ai ha $\left.{ }^{-1}\right)$ or fluroxypyr $\left(0.14 \mathrm{~kg}\right.$ ai ha $\left.{ }^{-1}\right)$ in a greenhouse study on dicamba-resistant kochia inbreds (Nandula and Manthey 2002). Although a dicamba rate of 0.28 $\mathrm{kg}$ ae ha ${ }^{-1}$ was not evaluated previously, kochia control ranged from 70 to $76 \%$ with dicamba applied at $0.14 \mathrm{~kg} \mathrm{ha}^{-1}$ (Nandula and Manthey 2002; Tonks and Westra 1997). Consistent with our results, Lloyd et al. (2011) reported 68 to $77 \%$ kochia control 4 WAT with dicamba + diflufenzopyr POST at similar rates. Knezevic et al. (2009) also observed $<90 \%$ control of $10-\mathrm{cm}$-tall kochia plants treated with glyphosate $\left(1.059 \mathrm{~kg} \mathrm{ae} \mathrm{ha}^{-1}\right)$ in Gly-R soybean. Compared to our results, others reported greater kochia control (75 to 90\%) with bromoxynil + MCPA applied even at lower rates (0.2 to $0.3 \mathrm{~kg}$ ai ha ${ }^{-1}$ ) (Tonks and Westra 1997 ; Wolf et al. 2000), and control with glufosinate in our study was lower $\left(52 \%\right.$ with $0.593 \mathrm{~kg}^{\text {ai ha }} \mathrm{ha}^{-1}$ glufosinate) compared to that obtained (77\% with $0.42 \mathrm{~kg} \mathrm{ha}^{-1}$ glufosinate) in a study conducted by Eberlein et al. (1993).

Alternative POST Herbicides for Gly-R Kochia Control. Visual Assessment of Control. The interaction of accession by treatment was significant 
Table 8. Control and shoot dry weight (percentage of nontreated) of Gly-S and Gly-R kochia accessions from Montana 3 wk after treatment with various POST herbicides labeled for corn or soybean. ${ }^{\text {a,b }}$

\begin{tabular}{|c|c|c|c|c|c|c|c|}
\hline Herbicide(s) & Rate(s) & Gly-S & GIL01 & CHES01 & CHES02 & JOP01 & $P$ value \\
\hline Cloransulam-methyl $^{\mathrm{d}}$ & 0.017 & $93 \mathrm{a}$ & $37 \mathrm{c}$ & $29 \mathrm{e}$ & $12 \mathrm{e}$ & $12 \mathrm{~d}$ & 0.0002 \\
\hline Lactofen $^{\mathrm{e}}$ & 0.218 & $91 \mathrm{ab}$ & $89 \mathrm{a}$ & $89 \mathrm{ab}$ & $84 \mathrm{a}$ & $74 \mathrm{ab}$ & 0.0007 \\
\hline$S$-metolachlor + mesotrione ${ }^{\mathrm{d}}$ & $1.866+0.184$ & $78 \mathrm{~d}$ & $64 \mathrm{~b}$ & $77 \mathrm{c}$ & $64 c$ & $71 \mathrm{~b}$ & 0.0018 \\
\hline Tembotrione $^{\mathrm{e}}$ & 0.089 & $56 \mathrm{e}$ & $41 \mathrm{c}$ & $38 \mathrm{~d}$ & $34 \mathrm{~d}$ & $33 \mathrm{c}$ & $<0.0001$ \\
\hline Topramezone $^{\mathrm{e}}$ & 0.018 & $11 \mathrm{f}$ & $11 \mathrm{~d}$ & $28 \mathrm{e}$ & $33 \mathrm{~d}$ & $16 \mathrm{~d}$ & 0.0004 \\
\hline \multirow[t]{2}{*}{ Topramezone + atrazine ${ }^{\mathrm{e}}$} & $0.018+0.560$ & $84 \mathrm{c}$ & 88 a & $91 \mathrm{a}$ & $75 \mathrm{~b}$ & $72 \mathrm{~b}$ & 0.0001 \\
\hline & & \multicolumn{6}{|c|}{-Dry weight (\% of nontreated) } \\
\hline Cloransulam-methyl $^{\mathrm{d}}$ & 0.017 & $8 \mathrm{f}$ & $66 \mathrm{~b}$ & $77 \mathrm{a}$ & $86 \mathrm{a}$ & $76 \mathrm{a}$ & $<0.0001$ \\
\hline Fomesafen $^{\mathrm{d}}$ & 0.459 & $19 \mathrm{~d}$ & $25 \mathrm{~d}$ & $27 \mathrm{c}$ & $38 \mathrm{c}$ & $35 \mathrm{~d}$ & 0.0057 \\
\hline Lactofen $^{e}$ & 0.218 & $17 \mathrm{de}$ & $28 \mathrm{~d}$ & $21 \mathrm{~d}$ & $29 \mathrm{~d}$ & $36 \mathrm{~cd}$ & 0.0223 \\
\hline Topramezone & 0.018 & $88 \mathrm{a}$ & $88 \mathrm{a}$ & $77 \mathrm{a}$ & $74 \mathrm{~b}$ & $69 \mathrm{a}$ & 0.0143 \\
\hline Topramezone + atrazine ${ }^{\mathrm{e}}$ & $0.018+0.560$ & $17 \mathrm{de}$ & $23 \mathrm{~d}$ & $18 \mathrm{~d}$ & $36 \mathrm{~cd}$ & $41 \mathrm{~d}$ & $<0.0001$ \\
\hline
\end{tabular}

a Abbreviations: Gly-S, glyphosate-susceptible accession, Huntley, MT; Gly-R, glyphosate-resistant; GIL01, Gly-R accession, Gildford, MT; JOP01, Gly-R accession, Joplin, MT; CHES01, Gly-R accession 1, Chester, MT; CHES02, Gly-R accession 2, Chester, MT.

${ }^{\mathrm{b}}$ Herbicide treatments were applied to 8 - to 10 -cm-tall kochia plants.

${ }^{\mathrm{c}}$ For percent control and shoot dry weight, means for a kochia accession within a column followed by similar lowercase letters are not significantly different based on Fisher's protected LSD test at $\mathrm{P}<0.05$.

${ }^{\mathrm{d}}$ Nonionic surfactant (NIS) at $0.25 \%(\mathrm{v} / \mathrm{v})$ was included.

e Methylated seed oil (MSO) at 1\% (v/v) was included.

$(\mathrm{P}<0.0005)$, indicating that kochia accessions showed differential response to POST herbicides (labeled for corn/soybean) evaluated in the study. The differential response of the accessions might be attributed to the high genetic diversity of kochia (Kumar et al. 2014; Mengistu and Messersmith 2002).

For the Gly-S kochia accession tested, cloransulam-methyl, lactofen, and tembotrione + atrazine provided 91 to $94 \%$ control 3 WAT (Table 8). Control with fomesafen (87\%) did not differ from control with lactofen (91\%). The addition of atrazine to tembotrione or topramezone improved kochia control by 38 and $73 \%$, respectively, compared with tembotrione or topramezone alone 3 WAT. Control of the Gly-S accession with $S$-metolachlor + mesotrione was $78 \% 3$ WAT.

Besides modest differences in response to herbicides across accessions, control of Gly-R kochia was 71 to $91 \%$ at 3 WAT with lactofen, fomesafen, tembotrione + atrazine, or topramezone + atrazine
(Table 8). Control of the four Gly-R kochia accessions with $S$-metolachlor + mesotrione was 64 to $77 \%$. Gly-R kochia control with cloransulammethyl, tembotrione alone, or topramezone alone was poor $(\leq 41 \%)$. The lower control of the Gly-R accessions compared with the Gly-S accession observed with cloransulam-methyl was because the Gly-R accessions were also resistant to the ALSinhibitor herbicide (data not shown).

Shoot Dry Weight Response. The interaction of accession by treatment was significant $(\mathrm{P}<$ 0.0001). In general, shoot dry weight reductions of treated kochia accessions were consistent with the control ratings for the herbicides tested. For the Gly-S accession, cloransulam-methyl and tembotrione + atrazine reduced kochia shoot dry weight by 89 to $92 \% 3$ WAT followed by fomesafen, lactofen, and topramezone + atrazine treatments $(82 \%$ average reduction in shoot dry weight) (Table 8). For the Gly-R accessions, lactofen, fomesafen, tembotrione + atrazine, or 
topramezone + atrazine were the best treatments tested, and reduced shoot dry weight up to $82 \%$ 3 WAT. S-metolachlor + mesotrione reduced shoot dry weight of Gly-R accessions up to $70 \%$. Consistent with poor control, cloransulam-meth$\mathrm{yl}$, tembotrione-, and topramezone-treated Gly-R plants produced greater shoot dry weight among all treatments (Table 8).

In summary, the PRE herbicide field trials suggest that acetochlor + atrazine, pyroxasulfone + atrazine, and $S$-metolachlor + atrazine + mesotrione would provide effective season-long kochia control in corn/grain sorghum. Sulfentrazone and metribuzin would provide effective residual control of kochia in soybean. Evident from the POST herbicide field trials, paraquat plus atrazine, paraquat plus linuron, and paraquat plus metribuzin would be effective burndown programs for kochia control in corn/grain sorghum, corn/ fallow, and soybean, respectively. POST kochia control with glyphosate was $88 \% 5$ WAT, and did not differ from bromoxynil + fluroxypyr (labeled in wheat/barley), tembotrione + atrazine (labeled in corn), and topramezone + atrazine (labeled in corn) programs.

Results from the greenhouse experiments suggest that atrazine + tembotrione or atrazine + topramezone would be an effective POST option for Gly-R kochia control in Gly-R corn. Lactofen or fomesafen could potentially provide effective control of Gly-R kochia in Gly-R soybean. Additionally, cloransulam-methyl would be an effective alternative product for Gly-R kochia control in Gly-R soybean, unless kochia plants are resistant to the ALS-inhibitor herbicide.

In conclusion, PRE soil-residual herbicide should serve as a foundation for kochia control programs. As kochia accessions with resistance to group 9 (glyphosate), group 2 (sulfonylureas and imidazolinones), group 5 (atrazine), or group 4 herbicides (dicamba, fluroxypyr) continue to spread and impact larger acreages in the northwestern and north central United States, incorporation of additional effective modes of action (investigated in this research) will be needed to control kochia. Kochia is a highly variable species, and the results reported in this article may not be consistent for all accessions. Growers managing kochia in their fields should pay greater attention to the response of kochia to the herbicides they use, and use a diversity of herbicides and other weed management techniques to avoid selecting for additional herbicide resistance in kochia accessions on their farms.

\section{Acknowledgments}

The authors would like to acknowledge Nicholas Reichard and Shane Leland for their technical assistance. Partial funding from Monsanto Company to conduct this research is gratefully acknowledged.

\section{Literature Cited}

Baker DV, Withrow JR, Brown CS, Beck KG (2010) Tumbling: use of diffuse knapweed (Centaurea diffusa) to examine an understudied dispersal mechanism. Invasive Plant Sci Manage 3:301-309

Beckie HJ (2006) Herbicide-resistant weeds: management tactics and practices. Weed Technol 20:793-814

Beckie HJ, Blackshaw RE, Low R, Hall LM, Sauder CA, Martin S, Brandt EN, Shirriff SW (2013) Glyphosate- and acetolactate synthase inhibitor-resistant kochia (Kochia scoparia) in western Canada. Weed Sci 61:310-318

Christoffoleti PJ, Westra PB, Moore F (1997) Growth analysis of sulfonylurea-resistant and -susceptible kochia (Kochia scoparia). Weed Sci 45:691-695

Cranston HJ, Kern AJ, Hackett JL, Miller EK, Maxwell BD, Dyer WE (2001) Dicamba resistance in kochia. Weed Sci 49:164-170

Dahl GK, Dexter AG, Nalewaja JD (1982) Kochia competition and control in wheat. Proc North Cent Weed Control Conf $37: 15-16$

Dille JA, Stahlman PW, Geier PW, Riffel JD, Currie RS, Wilson RG, Sbatella GM, Westra P, Kniss AR, Moechnig MJ, Cole RM (2012) Kochia emergence profiles across the central Great Plains. Proc Weed Sci Soc Am 52:122

Durgan BR, Dexter AG, Miller SD (1990) Kochia (Kochia scoparia) interference in sunflower (Helianthus annus). Weed Technol 4:52-56.

Eberlein CV, Fore ZA (1984) Kochia biology. Weeds Today 15:5-6

Eberlein CV, Guttieri MJ, Fletcher FN (1993) Broadleaf weed control in potatoes (Solanum tuberosum) with postemergence directed herbicides. Weed Technol 7:298-303

Forcella F (1985) Spread of kochia in the northwestern United States. Weeds Today 16:4-6

Friesen LF, Beckie HJ, Warwick SI, Van Acker RC (2009) The biology of Canadian weeds. 138. Kochia scoparia (L.) Schrad. Can J Plant Sci 89:141-167

Heap I (2014) International Survey of Herbicide Resistant Weeds. http://www.weedscience.org Accessed January 9, 2014

Jha P, Kumar V, Reichard N (2013) Preemergence residual herbicides: a valuable tool for weed control in glyphosateresistant corn. Proc Weed Sci Soc Am 33 
Knezevic SZ, Datta A, Scott J, Klein RN, Golus J (2009) Problem weed control in glyphosate-resistant soybean with glyphosate tank mixes and soil-applied herbicides. Weed Technol 23:507-512

Kumar V, Jha P, Reichard N (2014) Occurrence and characterization of kochia (Kochia scoparia) populations with resistance to glyphosate in Montana. Weed Technol 28:122130

Lloyd KL, Johnson JM, Gover AE, Sellmer JC (2011) Preemergence and postemergence suppression of kochia on rights-of-way. Weed Technol 25:292-297

Mengistu LW, Messersmith CG (2002) Genetic diversity of kochia. Weed Sci 50:498-503

Nandula VK, Manthey FA (2002) Response of kochia (Kochia scoparia) inbreds to 2,4-D and dicamba. Weed Technol 16:50-54

Norsworthy, JK, Ward SM, Shaw DR, Llewellyn RS, Nichols RL, Webster TM, Bradley KW, Frisvold G, Powles SB, Burgos NR, Witt WW, Barrett M (2012) Reducing the risks of herbicide resistance: best management practices and recommendations. Weed Sci 60:31-62

Preston C, Belles DS, Westra PH, Nissen SJ, Ward SM (2009) Inheritance of resistance to the auxinic herbicide dicamba in kochia (Kochia scoparia). Weed Sci 57:43-47

Primiani MM, Cotterman JC, Saari LL (1990) Resistance of Kochia scoparia to sulfonylurea and imidazolinone herbicides. Weed Technol 4:169-172

Reddy SS, Stahlman PW, Geier PW, Thompson CR (2012) Weed control and crop safety with premixed s-metolachlor and sulfentrazone in sunflower. Am J Plant Sci 3:1625-1631

Sbatella GM, Wilson RG (2010) Isoxaflutole shifts kochia (Kochia scoparia) populations in continuous corn. Weed Technol 24:392-396

Schwinghamer TD, Van Acker RC (2008) Emergence timing and persistence of kochia (Kochia scoparia). Weed Sci 56:37-41
Stahlman PW, Olson BLS, Thompson, CR, Zollinger RK (2010) Pyroxasulfone (KIH-485) for weed control in sunflower. Pages 1-7 in Proceedings of the 1st Australian Summer Grains Conference. Gold Coast, Australia

Stallings GP, Thill DC, Mallory-Smith CA, Shafii B (1995) Pollen-mediated gene flow of sulfonylurea-resistant kochia (Kochia scoparia). Weed Sci 43:95-102

Stephenson DO IV, Bond JA, Landry RL, Edwards HM (2013) Effect of coapplied glyphosate, pyrithiobac, pendimethalin, or $S$-metolachlor on cotton injury, growth, and yield. Weed Technol 27:305-309

Tonks DJ, Westra P (1997) Control of sulfonylurea-resistant kochia (Kochia scoparia). Weed Technol 11:270-276

Waite J, Thompson CR, Peterson DE, Currie RS, Olson BLS, Stahlman PW, Khatib KA (2013) Differential kochia (Kochia scoparia) populations response to glyphosate. Weed Sci 61:193-200

Weatherspoon DM and Schweizer EE (1971) Competition between sugarbeets and five densities of kochia. Weed Sci 19:125-128

Wicks GA, Martin AR, Haack AE, Mahnken GW (1994) Control of triazine-resistant kochia (Kochia scoparia) in sorghum (Sorghum bicolor). Weed Technol 8:748-753

Wicks GA, Martin AR, Mahnken GW (1993) Control of triazine-resistant kochia (Kochia scoparia) in conservation tillage corn (Zea mays). Weed Sci 41:225-231

Wolf R, Clay SA, Wrage LJ (2000) Herbicide strategies for managing kochia (Kochia scoparia) resistant to ALS-inhibiting herbicides in wheat (Triticum aestivum) and soybean (Glycine max). Weed Technol 14:268-273

Received March 21, 2014, and approved August 24, 2014. 